\title{
PROGRAMASI LINEAR UNTUK PENCARIAN DIAMETER PIPA OPTIMAL PADA SISTEM JARINGAN PIPA DISTRIBUSI AIR BERSIH
}

\author{
Linear Programming for Search Optimum Diameter Pipe on Network Pipe Distribution Water \\ Supply
}

\section{Sulianto}

Jurusan Teknik Sipil-Fakultas Teknik Univeristas Muhammadiyah Malang

Alamat korespondensi : Jalan Raya Tlogomas 246 Malang 65144

\begin{abstract}
In determining the optimum pipe diameter in the activities of the water distribution system design is highly dependent on the objective function and design criteria expressed as a function of its boundary. On gravity flow conditions, the performance of a network can be assessed from the minimum cost of investment pipeline and high minimum pressure difference relative to each service node. Therefore, the purpose of optimization in designing pipelines with gravity flow directed towards minimizing both. Linear Programming $(L P)$ is a method that is very popular and reliable in solving optimization problems containing linear functions. Besides the simplicity of its functions, the ease in completing the equation makes the LP system more attractive for application in solving various cases optimization. This work aims to determine the level of enforcement in solving optimization problems LP diameter pipe in the open pipe network in the water distribution system. Testing the model is done by using the data that is considered to represent a hypothetical pipeline on a flat service area (case-1) and a service area on the undulating topography (case 2). Results of the analysis in both cases shows that the LP models is quite consistent and can provide optimum solutions appropriate objective function and barrier function set.
\end{abstract}

Keyword :Linear Program, diameter, pipelines, optimization.

\begin{abstract}
Abstrak
Upaya menemukan diameter pipa optimum dalam kegiatan perancangan sistim distribusi air bersih sangat tergantung dari fungsi tujuan dan kriteria desain yang dinyatakan sebagai fungsi pembatasnya. Pada kondisi aliran gravitasi maka kinerja suatu jaringan dapat dinilai dari biaya minimum investasi pipa dan perbedaan minimum tinggi tekanan relatif pada setiap simpul layanan. Oleh sebab itu tujuan optimasi dalam merancang jaringan pipa dengan aliran gravitasi diarahkan pada upaya minimalisasi kedua hal tersebut. Linier Programming (LP) merupakan sebuah metode yang sangat populer dan handal dalam memecahkan masalah optimasi yang mengandung fungsi-fungsi linier. Disamping kesederhanaan fungsinya, faktor kemudahan dalam menyelesaikan sistim persamaan menjadikan LP semakin menarik untuk diterapkan dalam memecahkan berbagai kasus optimasi. karya ini bertujuan untuk mengetahui tingkat pemberlakuan LP dalam menyelesaikan masalah optimasi diameter pipa pada jaringan pipa terbuka dalam sistim distribusi air bersih. Pengujian model dilakukan dengan menggunakan data hipotetik yang dianggap mewakili jaringan pipa pada daerah layanan datar (kasus-1) dan daerah layanan pada topografi bergelombang (kasus-2). Hasil analisis pada kedua kasus tersebut menunjukkan bahwa model LP cukup konsisten dan dapat memberikan solusi optimum sesuai fungsi tujuan dan fungsi pembatas yang ditetapkan.
\end{abstract}

Kata kunci : Program Linier, diameter, jaringan pipa, optimasi.

\section{PENDAHULUAN}

Kinerja pelayanan sistem penyediaan air bersih tidak hanya ditentukan oleh besarnya kapasitas sumber, namun volume air tersebut juga harus sampai pada simpul-simpul layanan dengan aliran dan tinggi tekanan yang memadai sesuai kebutuhan.
Disamping itu efektivitas sebuah jaringan pipa juga dapat diukur dari besarnya biaya investasi dan operasionalnya selama usia guna yang ditetapkan. Upaya menemukan diameter pipa optimal yang menghasilkan kinerja sistim jaringan yang memuaskan hanya dapat ditentukan melalui teknik 
optimasi yang memiliki dua fungsi tujuan sekaligus, yaitu ; minimasi biaya investasi jaringan dan minimasi beda nilai tinggi energi relatif pada setiap simpul layanan. Sebagai fungsi pembatas umum dalam menyelesaikan fungsi tujuan tersebut adalah fungsi-fungsi hidrolis sistim persamaan perpipaan dan karakteristik fisik serta kriteria-kriteria perencanaan lain yang dilibatkan. Pada tulisan ini masalah tersebut didekati dengan memanfaatkan kelebihan metode Linier Programming (LP). Pembahasan difokuskan pada sistim jaringan terbuka dan pengujian model yang dikembangkan menggunakan data hipotetik, yaitu data yang mewakili kawasan dengan kondisi topografi datar dan relatif bergelombang. Hasil analisis dari masukan dua karakter data tersebut diharapkan dapat menjadi indikator tingkat konsistensi dan keandalan sistim persamaan yang dikembangkan.

\section{Persamaan Hidrolis Jaringan Pipa}

\section{Prinsip dasar aliran pada jaringan pipa}

Dalam analisis jaringan pipa harus dipenuhi prinsip-prinsip persamaan dasar kontinuitas dan energi sebagai berikut : 1) aliran didalam pipa harus memenuhi hukum-hukum kehilangan tinggi tekan untuk aliran pipa tunggal, 2) jumlah aliran yang masuk kedalam sistem jaringan harus sama dengan aliran yang meninggalkannya dan 3) aliran yang masuk pada suatu simpul harus sama dengan jumlah aliran yang meninggalkannya. Aliran pada sebuah elemen pipa harus memenuhi persamaan kekekalan energi spesifik seperti ditunjukkan Gambar 1 berikut.

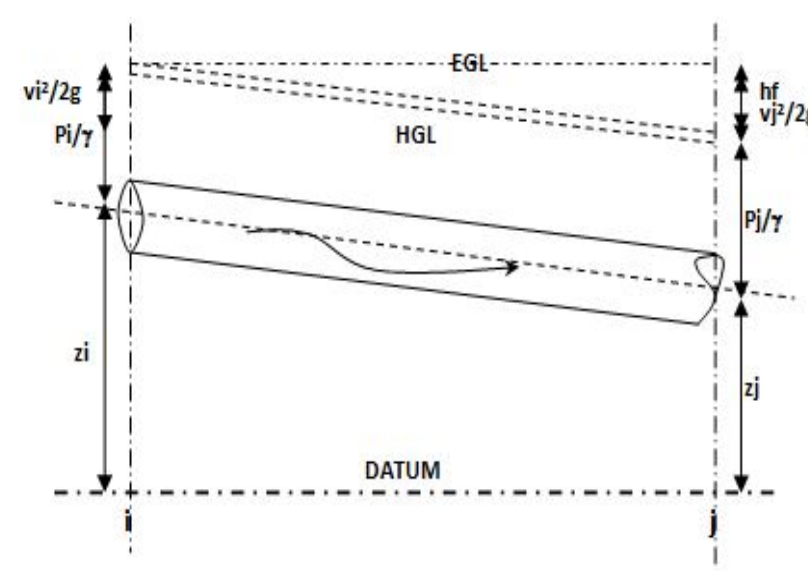

Gambar 1. Elemen aliran pipa
Dari Gambar 1 berlaku ; $E_{i}=E_{j}+h f$, atau lebih rinci ;

$$
z_{i}+\frac{P_{i}}{\gamma}+\frac{v_{i}^{2}}{2 g}=z_{j}+\frac{P_{j}}{\gamma}+\frac{v_{j}^{2}}{2 g}+h f
$$

dimana;

$\mathrm{Ei}=$ Tinggi energi pada simpul $\mathrm{i}(\mathrm{m})$,

$\mathrm{Ej}=$ Tinggi energi pada simpul $\mathrm{j}(\mathrm{m})$,

$\mathrm{hf}=$ Kehilangan energi sepanjang elemen pipa (m),

$\mathrm{zi}=$ tinggi elevasi simpul $\mathrm{i}(\mathrm{m})$;

$\mathrm{zj}=$ tinggi elevasi simpul $\mathrm{j}(\mathrm{m})$,

$\mathrm{Pi} / \mathrm{g}=$ tekanan di simpul $\mathrm{i}(\mathrm{m})$;

$\mathrm{Pj} / \mathrm{g}=$ tekanan di simpul $\mathrm{j}(\mathrm{m})$,

$\mathrm{v}=$ kecepatan aliran (m/detik),

$\mathrm{g}=$ percepatan gravitasi $\left(\mathrm{m} / \mathrm{detik}^{2}\right)$, dan

$\mathrm{hf}=$ kehilangan tinggi energi mayor losses (m).

Persamaan yang menyatakan hubungan nilai debit dengan kehilangan tinggi energi pada aliran pipa yang cukup luas digunakan adalah persamaan Darcy Weisbach dan Hazen-William. Persamaan Hazen-William dinyatakan dengan (Ranald V. Giles, $1996 ; 121)$ :

$$
Q=0.2785 . C_{H W} \cdot D^{2.63} \cdot S^{0.54}
$$

dengan;

$\mathrm{Q}=$ debit $\left(\mathrm{m}^{3} /\right.$ detik $)$;

$\mathrm{CHW}=$ Koefisien kekasaran dinding pipa oleh Hazen

William,

D = Diameter pipa (m);

$\mathrm{S} \quad=$ Kemiringan garis energi;

hf $\quad$ Kehilangan energi akibat gesekan batas (m), dan

$\mathrm{L}=$ Panjang elemen pipa (m).

\section{Keseimbangan aliran pada simpul pipa}

Dalam suatu percabangan pipa maka harus berlaku keseimbangan aliran pada setiap simpul percabangan, dimana jumlah aliran menuju simpul harus sama dengan jumlah aliran yang meninggalkan simpul. Pada suatu percabangan pipa seperti ditunjukkan Gambar 2, keseimbangan aliran pada simpul 2 dapat dinyatakan sebagai : 


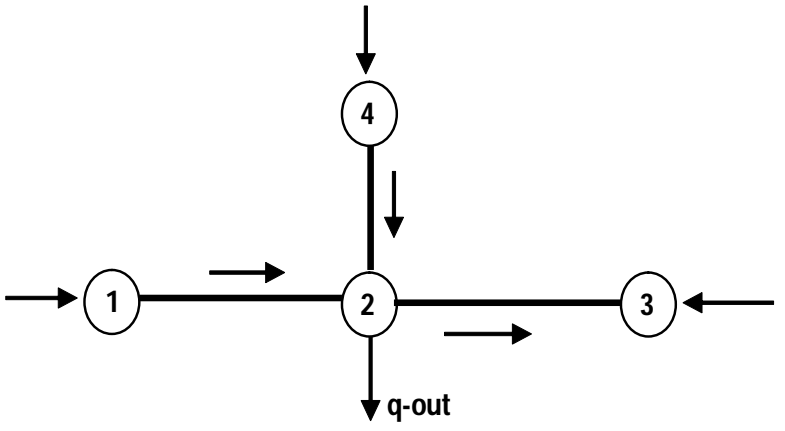

Gambar 2. Keseimbangan aliran di simpul

$$
Q_{1-2}+Q_{4-2}=Q_{2-3}+q-\text { out }
$$

dengan,

$\mathrm{Q}_{1-2}=$ debit pada elemen 1-2 ;

$\mathrm{Q}_{4-2}=$ debit pada elemen ;

$\mathrm{Q}_{2-3}=$ debit pada elemen 2-3 dan q-out $=$ debit keluar nyata.

\section{Persamaan tinggi energi pada sistim percabangan pipa}

Ditinjau sistim percabangan pipa seperti ditunjukkan Gambar 3. Jaringan tersebut terdiri dari 5 elemen pipa dan 5 simpul pelayanan serta sebuah tandon dengan aliran secara gravitasi. Bila $\mathrm{Ha}=$ tinggi energi absolute, $\mathrm{Hr}=$ tinggi energi relatif, $\mathrm{z}=$ elevasi simpul, hf=kehilangan tinggi energi, Qout=kebutuhan nyata dan El. Mat=elevasi muka air di tandon, maka berlaku persamaan keseimbangan energi pada tiap simpul layanan sebagai beriku:

Simpul $1: H a_{1}=E l . m a t-h f_{1}$ dan

$$
H r_{1}=H a_{1}-z_{1}
$$

Simpul 2: $H a_{2}=H a_{1}-h f_{2}$ dan

$$
\begin{aligned}
& H r_{2}=H a_{2}-z_{2} ; \ldots \\
& H a_{5}=H a_{2}-h f_{3} \text { dan }
\end{aligned}
$$

Simpul $3: H a_{5}=H a_{2}-h f_{3}$ dan $H r_{5}=H a_{5}-z_{5}$; dan seterusnya.

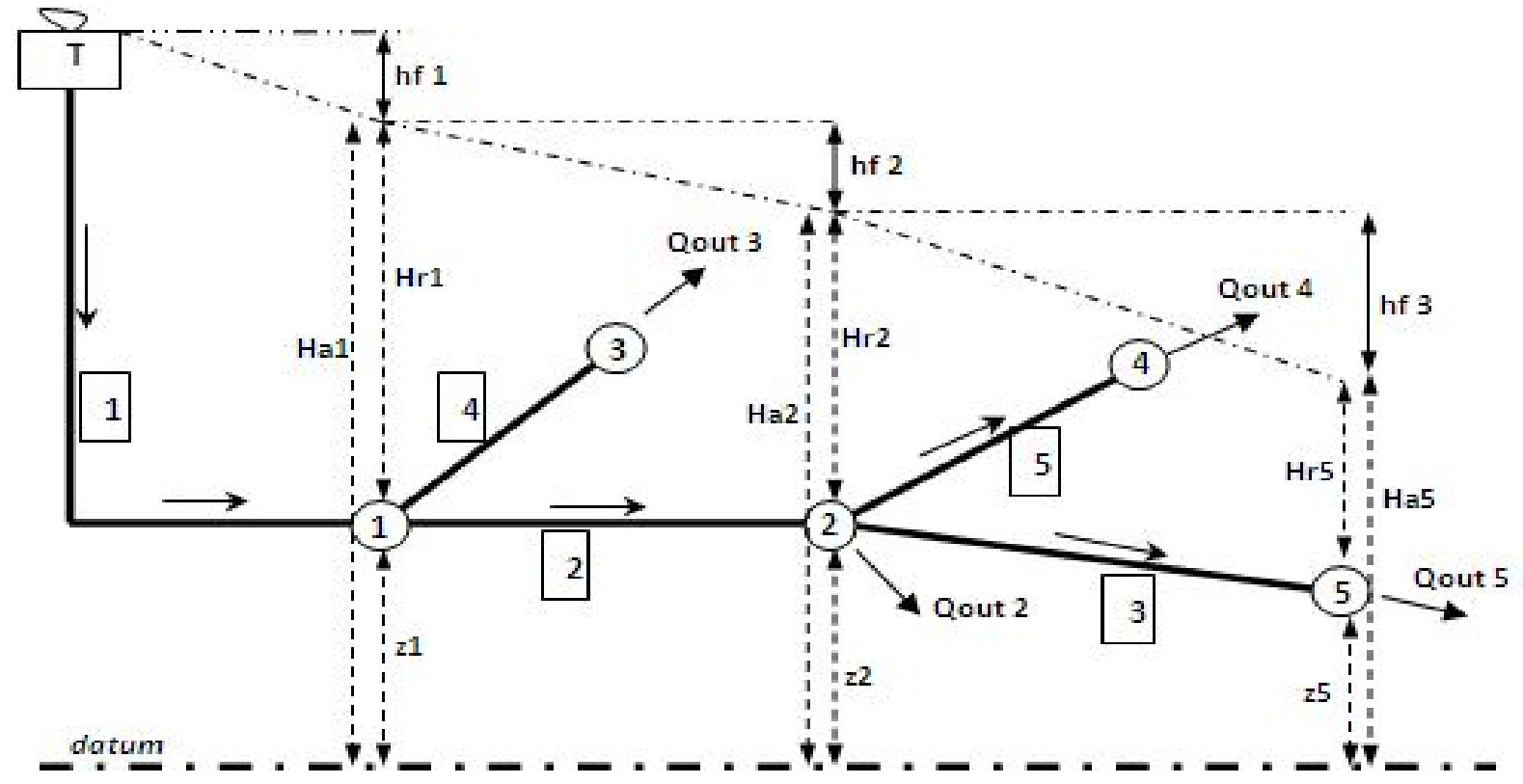

Gambar 3. Contoh jaringan percabangan pipa

\section{METODE PENELITIAN}

\section{Sistim Persamaan LP Pada Jaringan Pipa Terbuka}

Fungsi objective dalam permasalahan yang dipecahkan adalah minimasi biaya, dan fungsi pembatasnya adalah panjang elemen pipa, batas tekanan hidrolis pada simpul-simpul pelayanan dan kriteria lain yang diharapkan. Sistim Persamaan LP untuk pencarian diameter pada sistim jaringan terbuka dinyatakan sebagai berikut :

- Fungsi objective :

Minimasi : $\quad \mathrm{Z}=\sum_{(i, j) \in l} \sum_{m \in M_{1,3}} c_{i, j, m} X_{i, j, m}$

- $\quad$ Fungsi pembatas :

- Batasan panjang pipa, dimana untuk setiap panjang dari masing-masing diameter sama dengan panjang elemen pipa. 
$\sum_{m \in M_{1,3}} X_{i, j, m}=L_{i, j}$

- Batasan tekanan pada simpul-simpul layanan, dimana tekanan relatif pada setiap simpul-simpul layanan harus lebih dari tekanan minimum dan kurang dari tekanan maksimum yang direncanakan.

$$
\begin{aligned}
& H_{\text {min,n } n} \leq H_{8}+E_{P}- \\
& \sum_{(i, j) \in l} \sum_{m \in M_{1,3}} J_{i, j, m} X_{i, j, m} \leq H_{\max , i, j}
\end{aligned}
$$

- Non-negativitas

$$
X_{i, j, m} \geq 0
$$

dimana ;

$M_{i, j} \quad=$ calon diameter pipa untuk pipa penghubung $\mathrm{i}$ dan $\mathrm{j}$.

$C_{i, j, m} \quad=$ biaya panjang per unit dari diameter untuk penghubung kutub $\mathrm{i}$ dan $\mathrm{j}$.

I =perangkat pipa penghubung yang menggambarkan jaringan.

$I_{n} \quad=$ perangkat pipa yang menggambarkan jalur pada kutub $n$ (titik pengiriman $n$ )

$L_{i, j} \quad=$ =panjang penghubung jaringan kutub $\mathrm{i}$ dan $\mathrm{j}$

$J_{i, j, m} \quad=$ Slope hidraulis dari diameter pipa $\mathrm{m}$ yang menghubungkan kutub i dan $\mathrm{j}$, dapat dihitung dengan persamaan DarcyWeisbach, Hazen William atau persamaan lainnya.

$H_{8} \quad$ = peningkatan yang diketahui mengenai sumber air yang mana merupakan kutub tetap

$E_{P} \quad=$ energi utama yang diketahui ditambahkan pada sistem

$H_{\text {min, } n}=$ kebutuhan minimum pada titik pengiriman $\mathrm{n}$

$H_{\text {max }, n}=$ kebutuhan maksimum pada titik pengiriman $n$

$N=$ angka total titik pengiriman

\section{HASIL DAN PEMBAHASAN}

\section{Data Karakteristik Jaringan Pipa}

- Data jaringan perpipaan,

jaringan pipa yang dibahas dalam tulisan ini secara skematis ditunjukkan pada Gambar 4. Sistim tersebut merupakan jaringan terbuka dengan 23 elemen dan 23 simpul. Sumber air terletak pada elevasi yang lebih tinggi sehingga berlaku aliran gravitasi. Release untuk memenuhi kebutuhan nyata pada 15 simpul, yaitu simpul 4, 6, 7, 8, 10, 11, 12, 14, 15, 16, 18, $19,21,22$ dan 23.

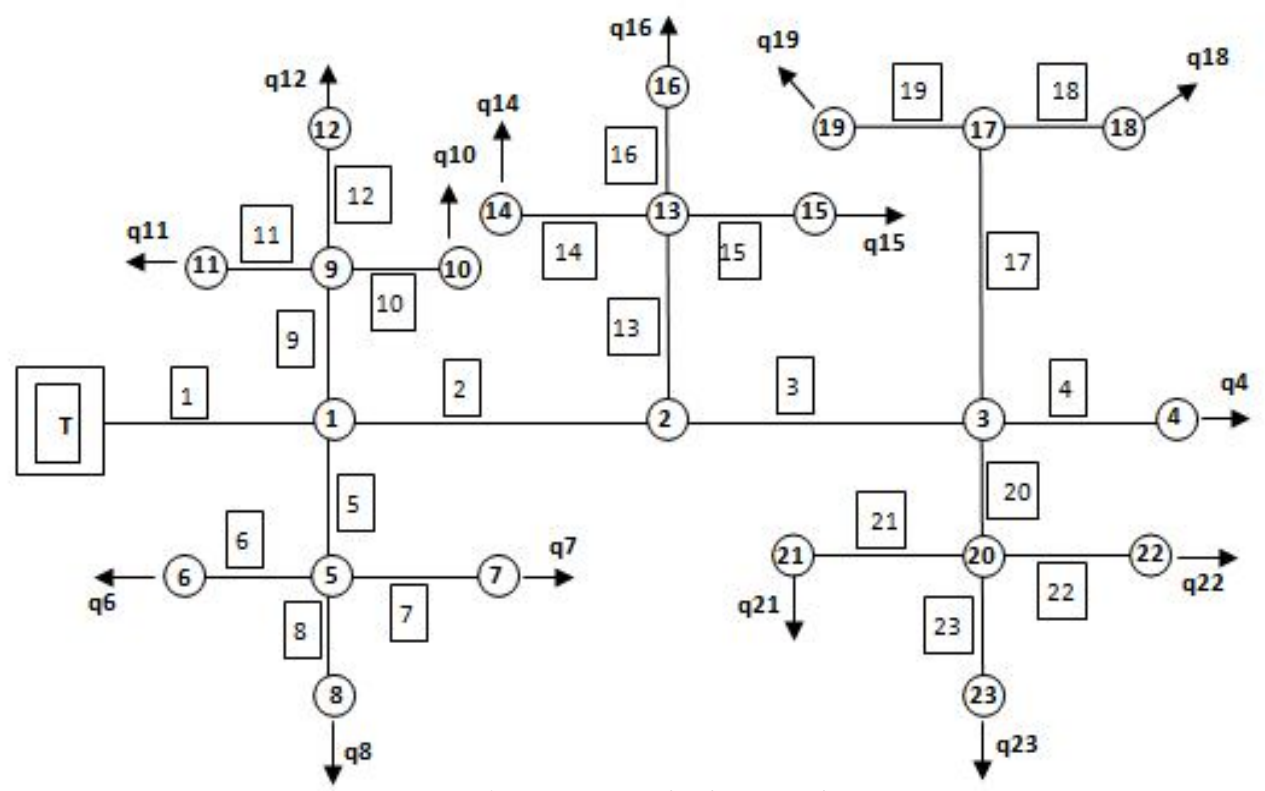

Gambar 4. Data jaringan pipa

- Data karakteristik elemen dan simpul, karakteristik elemen pipa dan simpul yang dipecahkan diuraikan pada Tabel 1 dan Tabel 2. Terdapat 2 kasus yang akan dipecahkan, yaitu Kasus-1 : jaringan pada kondisi daerah dengan topografi datar dan kasus-2: dianggap mewakili jaringan pada topografi yang bergelombang. Hasil analisis dari kedua kasus 
tersebut diharapkan dapat menjadi indikator

untuk menilai konsistensi sistim persamaan yang dikembangkan.

Tabel 1. Karakteristik elemen pipa dan karakteristik simpul

\begin{tabular}{cccccc}
\hline No & CHW & L & No & CHW & L \\
& & $(\mathrm{m})$ & & & $(\mathrm{m})$ \\
\hline 1 & 120 & 300 & 13 & 120 & 300 \\
2 & 120 & 300 & 14 & 120 & 300 \\
3 & 120 & 300 & 15 & 120 & 300 \\
4 & 120 & 300 & 16 & 120 & 300 \\
5 & 120 & 300 & 17 & 120 & 300 \\
6 & 120 & 300 & 18 & 120 & 300 \\
7 & 120 & 300 & 19 & 120 & 300 \\
8 & 120 & 300 & 20 & 120 & 300 \\
9 & 120 & 300 & 21 & 120 & 300 \\
10 & 120 & 300 & 22 & 120 & 300 \\
11 & 120 & 300 & 23 & 120 & 300 \\
12 & 120 & 300 & & & \\
\hline
\end{tabular}

\begin{tabular}{|c|c|c|c|c|c|c|c|}
\hline \multirow{2}{*}{ No } & \multirow{2}{*}{$\begin{array}{l}\text { Q_out } \\
\text { (1/detik) }\end{array}$} & \multicolumn{2}{|c|}{$\begin{array}{c}\text { Elevasi simpul } \\
(\mathrm{m})\end{array}$} & \multirow{2}{*}{ No } & \multirow{2}{*}{$\begin{array}{l}\text { Q_out } \\
\text { (1/detik) }\end{array}$} & \multicolumn{2}{|c|}{$\begin{array}{c}\text { Elevasi simpul } \\
(\mathrm{m})\end{array}$} \\
\hline & & $\begin{array}{c}\text { Kasus } \\
1\end{array}$ & $\begin{array}{c}\text { Kasus } \\
2\end{array}$ & & & $\begin{array}{c}\text { Kasus } \\
1\end{array}$ & $\begin{array}{c}\text { Kasus } \\
2\end{array}$ \\
\hline 1 & 0.00 & 0.00 & 5.00 & 13 & 0.00 & 0.00 & 4.00 \\
\hline 2 & 0.00 & 0.00 & 3.00 & 14 & 2.00 & 0.00 & 6.00 \\
\hline 3 & 0.00 & 0.00 & 4.00 & 15 & 2.00 & 0.00 & 5.00 \\
\hline 4 & 2.00 & 0.00 & 5.00 & 16 & 2.00 & 0.00 & 5.00 \\
\hline 5 & 0.00 & 0.00 & 6.00 & 17 & 0.00 & 0.00 & 3.00 \\
\hline 6 & 2.00 & 0.00 & 8.00 & 18 & 2.00 & 0.00 & 4.00 \\
\hline 7 & 2.00 & 0.00 & 7.00 & 19 & 2.00 & 0.00 & 5.00 \\
\hline 8 & 2.00 & 0.00 & 3.00 & 20 & 0.00 & 0.00 & 6.00 \\
\hline 9 & 0.00 & 0.00 & 2.00 & 21 & 2.00 & 0.00 & 8.00 \\
\hline 10 & 2.00 & 0.00 & 4.00 & 22 & 2.00 & 0.00 & 7.00 \\
\hline 11 & 2.00 & 0.00 & 7.00 & 23 & 2.00 & 0.00 & 3.00 \\
\hline 12 & 2.00 & 0.00 & 6.00 & & & & \\
\hline
\end{tabular}

- Karakteristik kandidat pipa yang akan dipasang

Kandidat diameter pipa dan asumsi biaya pipa terpasang diuraikan pada Tabel 2.

Tabel 2. Kandidat diameter pipa

\begin{tabular}{ccccccccc}
\hline Nomor & 1 & 2 & 3 & 4 & 5 & 6 & 7 & 8 \\
$\begin{array}{c}\text { Diameter } \\
\text { (inch) }\end{array}$ & $1 / 2^{\prime \prime}$ & $1 "$ & $2 "$ & $3 "$ & $4 "$ & $5 "$ & $6 "$ & $7 "$ \\
\hline Harga $\left(\mathrm{Rp} / \mathrm{m}^{\prime}\right)$ & 60,000 & 90,000 & 120,000 & 150,000 & 180,000 & 210,000 & 240,000 & 270,000 \\
\hline
\end{tabular}

\section{Biaya minimum}

Sesuai Gambar 4 dan pengembangan persamaan (4) hingga (7), maka diperoleh sebanyak 184 variabel panjang ruas pipa dari 23 elemen pipa. Selanjutnya dengan menggunakan program Solver pada EXCEL 7.0 serta data masukan elevasi muka air sumber +30.00 meter, kriteria tinggi tekanan relatif minimum pada simpul layanan +5.00 meter dan maksimum pada +10.00 meter, maka kondisi optimum dicapai pada total biaya minimum $\mathrm{Rp}$. 1.146.737.325,- untuk kasus-1 dan Rp. $1,179,560,373,-$ untuk kasus-2. Biaya minimum tersebut merupakan biaya total untuk pemasangan pipa sepanjang 6900 meter. Perbandingan panjang pipa sesuai diameter optimal yang diperoleh dari LP ditunjukkan pada Gambar 5. Gambar tersebut menunjukkan adanya perbedaan panjang pipa cukup signifikan terjadi pada diameter $1 / 2$ inchi.

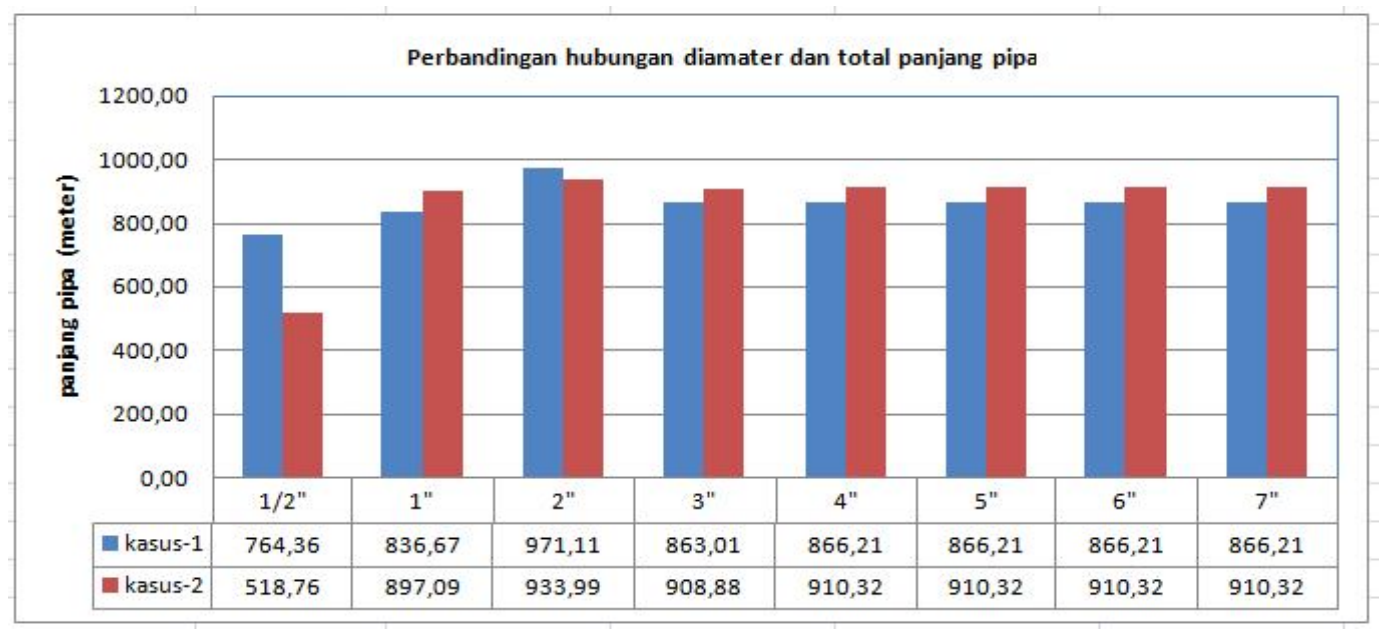

Gambar 5. Hubungan diameter optimum dan panjang pipa 


\section{Diameter optimum teoritis pada elemen pipa}

Perbandingan diameter optimum yang dihasilkan dari analisis kasus-1 dan kasus-2 dari setiap elemen pipa ditunjukan pada Gambar 6. Pada gambar tersebut terlihat bahwa pada setiap elemen pipa bisa terdiri dari ruas pipa dengan diameter yang bervariasi mulai dari diameter $1 / 2$ inchi hingga 7 inchi sesuai kandidat yang ditawarkan. Kasus-1 cenderung memiliki diameter optimum $1 \frac{1}{2}$ inchi yang lebih panjang dibanding hasil dari kasus-2, demikian sebaliknya kasus-2 memiliki diameter relatif besar cenderung lebih panjang dari kasus-1. Hasil tersebut menunjukkan betapa responsif-nya model yang dikembangkan dalam mengantisipasi perbedaan konstrain elevasi simpul yang diberikan. Mencermati hasil tersebut, maka sebuah elemen pipa akan terdiri dari banyak ruas dengan diameter yang bervariasi. Kondisi ini dapat dianggap sebagai sebuah kelemahan oleh karena sesungguhnya pada sebuah elemen pipa hanya dibebani oleh sebuah nilai aliran sehingga idealnya sebuah elemen pipa juga harus terdiri dari ruas-ruas pipa dengan diameter yang seragam. Disamping itu akibat diameter dari ruasruas pipa yang tidak seragam juga akan menyulitkan dalam implementasi di lapangan. Dalam sebuah kegiatan perancangan sistim distribusi disamping kondisi optimum harus dicapai, kondisi ideal sebuah jaringan juga harus dipenuhi. Guna maksud tersebut maka langkah justifikasi terhadap diameter optimal yang telah diperoleh dari analisis LP masih diperlukan, mengingat upaya memasukkan masalah tersebut kedalam fungsi constraint dari sistim persamaan LP sulit dilakukan.

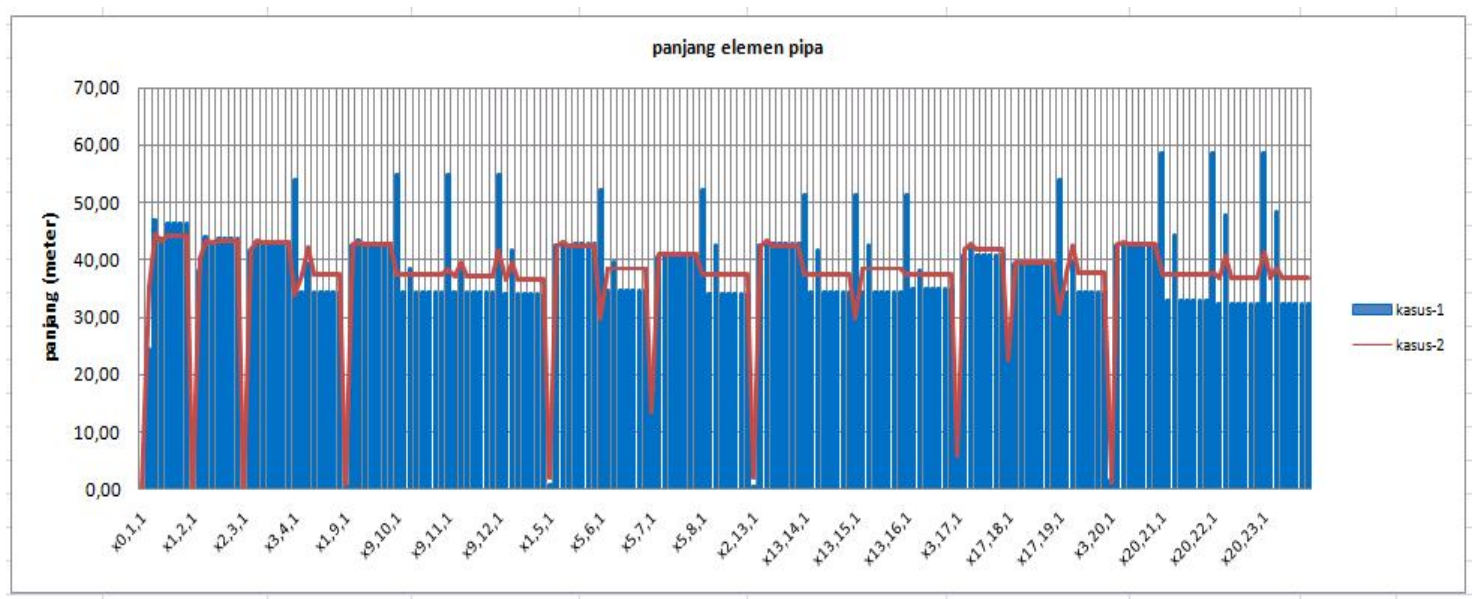

Gambar 6. Panjang elemen pada tiap ruas pipa

\section{Tinggi tekanan pada simpul layanan}

Tinggi tekan absolute dan tinggi tekan relatif pada setiap simpul layanan yang dihasilkan dari penyelesaian kasus-1 dan kasus-2 ditunjukkan pada Gambar 7 dan Gambar 8. Gambar 7 menunjukkan nilai tinggi tekan pada setiap simpul layanan dari kasus-1. Pada gambar tersebut terlihat bahwa tinggi tekan absolute dan relatif pada setiap simpul layanan terletak berimpit. Hal ini disebabkan oleh kedudukan elevasi setiap simpul layanan terletak pada elevasi yang sama, yaitu pada elevasi +0.00 meter. Tinggi tekan relatif minimum terletak pada elevasi +5.00 meter yang terjadi pada simpul layanan $7,18,21$, 22,23 , dan tinggi maksimum +10.00 meter terletak pada simpul-simpul layanan lainnya. Hasil tersebut menunjukkan bahwa kondisi optimum memang benar-benar tercapai pada konstrain tinggi tekan relatif ijin antara +5.00 hingga +10.00 meter sesuai kriteria yang ditetapkan. Pada penyelesaian kasus2 tinggi tekan yang terjadi pada setiap simpul layanan lebih bervariasi. Gambar 8 menunjukkan bahwa tekanan relatif dan absolute memiliki nilai yang berbeda sesuai kedudukan simpul-simpul pengambilan. Tekanan relatif minimum +5.00 meter terjadi pada simpul 7, 11, 12, 18, 22, 23, maksimum setinggi +10.00 meter terjadi pada simpul 4, 6, 15, 19 dan tinggi tekan pada simpul-simpul lainnya terletak diantaranya. Hasil tersebut juga menunjukkan bahwa kondisi optimum memang benar-benar tercapai sesuai fungsi pembatas yang diberikan, yaitu tinggi tekan relatif ijin terletak antara +5.00 meter sampai +10.00 meter. Hasil analisis kedua kasus tersebut menunjukkan bahwa sistim persamaan LP yang dikembangkan terbukti mampu melakukan pencarian diameter optimal sesuai fungsi tujuan dan fungsi constrain yang ditetapkan. 


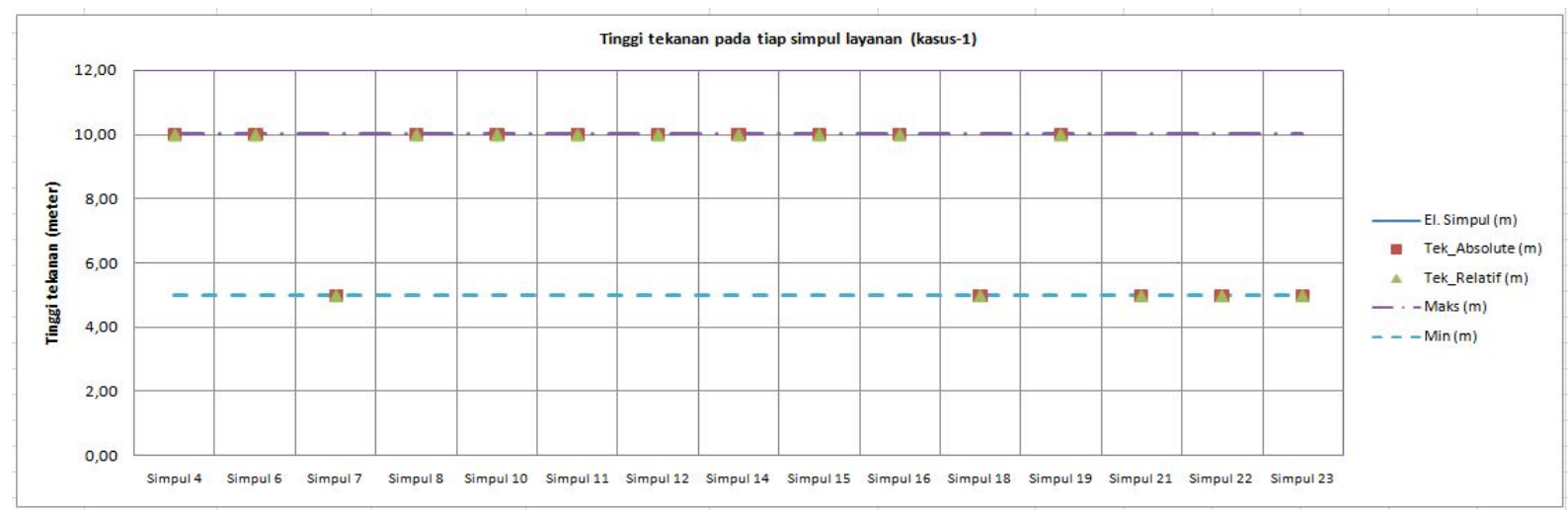

Gambar 7. Tinggi tekanan pada simpul-simpul layanan (kasus_1)

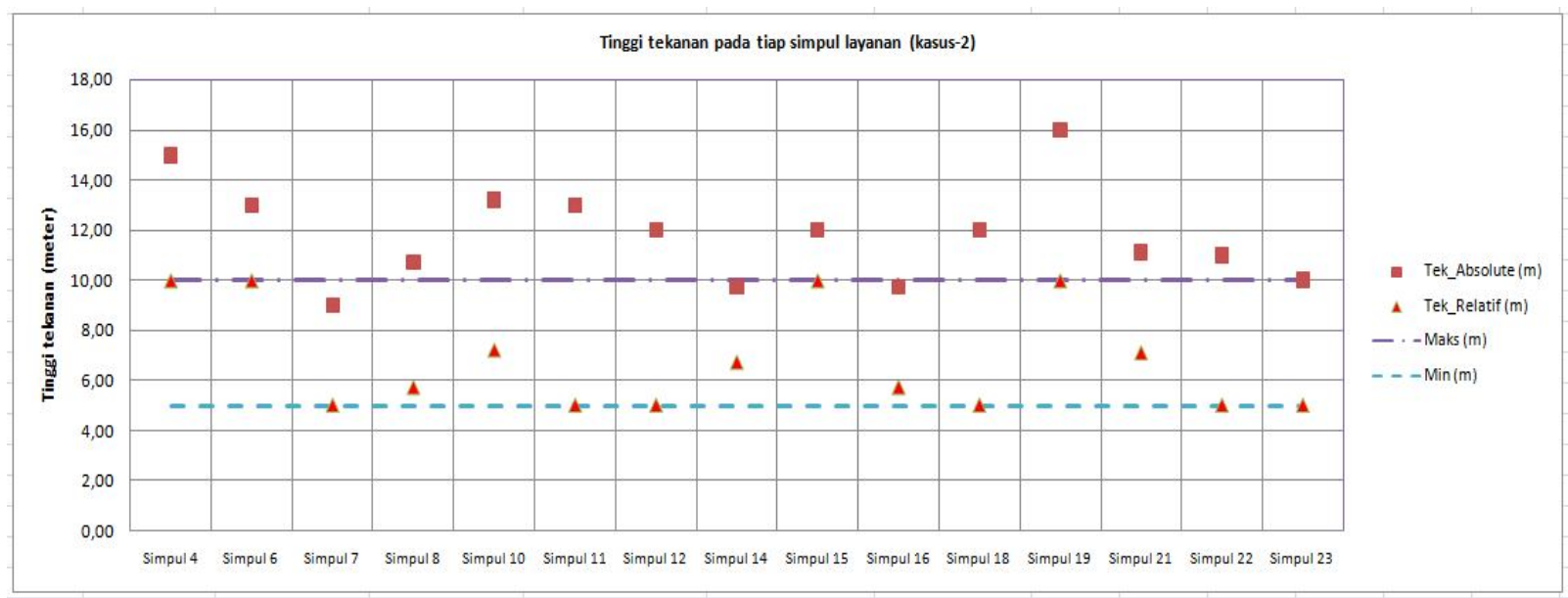

Gambar 8. Tinggi tekanan pada simpul-simpul layanan (kasus_2)

\section{Diameter pipa ekuivalen}

Bila dikehendaki diameter yang seragam untuk setiap elemen pipa, maka penerapan persamaan diameter equivalen dapat diterapkan, yaitu :

$D e q_{i, j}=\frac{X_{i, j, 1} * D k_{1}+X_{i, j, 2} * D k_{2}+X_{i, j, 3} * D k_{3}+\ldots \ldots .+X_{i, j, n} * D k_{n}}{L_{i, j}}$

dimana ;
$\mathrm{X}_{\mathrm{i}, \mathrm{j}, \mathrm{k}}=$ Panjang ruas elemen $\mathrm{i}, \mathrm{j}$ untuk diameter kandidat $\mathrm{k}$;

$\mathrm{Dk}_{\mathrm{j}}=$ Diameter kandidat $\mathrm{k}$;

$\mathrm{L}_{\mathrm{i}, \mathrm{j}}=$ panjang elemen $\mathrm{i}, \mathrm{j}$.

Dengan menggunakan persamaan (8) maka diperoleh diameter pipa ekuivalen untuk setiap elemen pipa pada penyelesaian kasus-1 dan kasus2 sebagai berikut.

$\operatorname{Deq}_{\mathrm{i}, \mathrm{j}}=$ Diameter equivalen elemen $\mathrm{i}, \mathrm{j}$;

Tabel 3. Diameter optimum elemen pipa

\begin{tabular}{ccc}
\hline Elemen & \multicolumn{2}{c}{ Diameter Ekuivalen (inchi) } \\
& Kasus-1 & Kasus-2 \\
\hline 0,1 & 4.00 & 4.00 \\
1,2 & 4.00 & 4.00 \\
2,3 & 4.00 & 4.00 \\
3,4 & 3.00 & 4.00 \\
1,9 & 4.00 & 4.00 \\
9,10 & 3.00 & 4.00 \\
9,11 & 3.00 & 4.00 \\
9,12 & 3.00 & 4.00 \\
1,5 & 4.00 & 4.00 \\
5,6 & 3.00 & 4.00 \\
5,7 & 4.00 & 4.00 \\
5,8 & 3.00 & 4.00 \\
\hline
\end{tabular}

\begin{tabular}{|c|c|c|}
\hline \multirow[t]{2}{*}{ Elemen } & \multicolumn{2}{|c|}{ Diameter Ekuivalen (inchi) } \\
\hline & Kasus-1 & Kasus-2 \\
\hline 2,13 & 4.00 & 4.00 \\
\hline 13,14 & 3.00 & 4.00 \\
\hline 13,15 & 3.00 & 4.00 \\
\hline 13,16 & 3.00 & 4.00 \\
\hline 3,17 & 4.00 & 4.00 \\
\hline 17,18 & 4.00 & 4.00 \\
\hline 17,19 & 3.00 & 4.00 \\
\hline 3,20 & 4.00 & 4.00 \\
\hline 20,21 & 3.00 & 4.00 \\
\hline 20,22 & 3.00 & 4.00 \\
\hline 20,23 & 3.00 & 4.00 \\
\hline
\end{tabular}




\section{KESIMPULAN DAN SARAN}

\section{Kesimpulan}

- Sistim persamaan LP yang dikembangkan mampu menyelesaikan masalah pencarian diameter optimum jaringan pipa terbuka dengan sangat memuaskan, baik pada sistim jaringan pada topografi datar maupun bergelombang.

- Dalam perancangan sistim distribusi air bersih jaringan terbuka, optimasi diameter pipa dengan menggunakan LP terdiri dari dua fungsi, yaitu fungsi tujuan berupa minimalisasi biaya investasi pipa dan fungsi pembatas berupa panjang setiap elemen pipa, syarat tekanan relatif minimum dan maksimum sesuai kriteria perencanaan yang ditetapkan.

- Kelemahan dari hasil yang diperoleh adalah setiap elemen pipa terdiri dari ruas-ruas pipa dengan diameter yang tidak seragam. Kondisi ini menjadi tidak ideal dalam implementasinya. Tambahan fungsi konstrain untuk mengantisipasi masalah tersebut sulit dilakukan mengingat fungsi hidrolis pipa sebenarnya adalah fungsi non linier. Bila dikehendaki hasil perancangan yang ideal maka harus dilakukan langkah justifikasi dengan menggunakan persamaan diameter ekuivalen untuk setiap elemen pipanya.

\section{Saran}

- Dalam karya ini masih menggunakan data yang bersifat hipotetik, untuk menguji tingkat konsistensi dan keandalan dari model yang dikembangkan pada dimensi yang lebih luas maka diperlukan pengujian dengan melibatkan data jaringan nyata di lapangan. Penerapan model pada ruang yang lebih luas tentu akan membutuhkan proses analisis yang lebih panjang dan komplek.

- $\quad$ Sistim persamaan hidrolis jaringan pipa yang dikembangkan dalam karya ini terbatas pada sistim jaringan pipa terbuka. Untuk sistim jaringan pipa yang bersifat tertutup (loop), maka analisisnya dapat menggunakan sistim persamaan matrik non linier atau dengan metode Hardy-Cross. Penyelesaian persamaan ini tidak mungkin dengan menggunakan LP, namun harus menggunakan metode lain yang lebih handal dalam menyelesaikan masalah optimasi yang bersifat non linier dan komplek. Pengembangan model dengan basis analisis ini dapat menjadi peluang untuk kegiatan penelitian berikutnya.

\section{DAFTAR PUSTAKA}

Darmajana, Dody A, 1997, "Optimasi Penggunaan Lahan Pertanian Dengan Program Linier", Jurnal Teknologi Indonesia, Jilid A, No. 1, Pusat Penelitian dan Pengembangan Fisika Terapan LIPI, ubang, Indonesia.

Gen M and Cheng R (1997), "Genetic Algorithms and Engineering Design", John Wiley and Sons, Inc., USA.

Hanselman \& Littlefield, 2001, MATLAB Bahasa Komputer Teknis, ANDI, Yogyakarta, Indonesia

Hiller, F.S, Lieberman, 1974, GJ, 2nd Ed, 791 pp. Operation Research, Holden-Day Inc., San Fransisco.

Mitchel, M, 1996, An introduction to genetic algorithms, MIT Press.

Sulianto, 2012,'Pencarian Diameter Pipa Optimum Pada Sistim Jaringan Terbuka Dengan

Algoritma Genetik", Laporan Penelitian Program PBP, UMM, Malang, Indonesia.

Sulianto, 2009, "Optimasi Parameter dengan Algoritma Genetik untuk meningkatkan kinerja

Model Tangki Standar pada analisa transformasi data hujan menjadi data aliran sungai", Laporan

Hasil Penelitian Program Penelitian Berorientasi Produk (PBP) UMM.

Suyanto, 2005, Algoritma Genetik dalam MATLAB, ANDI, Yogyakarta, Indonesia

W Mays \& Koung Tung, 1992, Hydrosystems Engineering and Management, McGrawHill, Inc, New York, Amerika Serikat. 